\title{
The Effect of Nostalgia Emotion to Brand Trust and Brand Attachment towards Repurchase Intention
}

\author{
Ayu Nur Hidayati ${ }^{a}$, Balderas Anastasia Isabela ${ }^{b}$, Yustika Shofiani Yuwananda ${ }^{c}$, Willy Gunadi ${ }^{\text {d }}$ \\ a, b, c, d Department of Business Management, Binus Business School, Jakarta, Indonesia \\ ayu.hidayati@binus.ac.id, balderas.isabela@binus.ac.id, ${ }^{\text {c } y u s t i k a . y u w a n a n d a 001 @ b i n u s . a c . i d, ~}{ }^{\mathrm{d}}$ wgunadi@binus.edu
}

Article History: Received: 10 November 2020; Revised 12 January 2021 Accepted: 27 January 2021; Published online: 5 April 2021

\begin{abstract}
A music concert or live music performance is an event that can give more experience to their audiences than just listening to music and this makes people go to their favorite musician's concert several times. This study has an objective to analyze the effect of nostalgia emotion to brand trust and brand attachment towards repurchase intentions by adding the repurchase intention from the previous studies as a new variable and applying it to the music industry, especially in the live music performance sector. The data used for this study were collected from 120 respondents who have watched music concerts or live music performances in Jakarta through an online survey and analyzed it by using SmartPLS in structural equation modeling (PLS-SEM). This study provides more understanding of the connection between each variable in the chosen industry and indicates that nostalgia emotion of a person can affect their brand trust and brand attachment towards their repurchase intention as the results.
\end{abstract}

Keywords:

\section{Introduction}

Music concerts or music festivals have been around for a long time in Indonesia, since 2015 a variety of live music events have emerged in Indonesia (Triwijanarko, 2017). One of the reasons music lovers come to a music concert held in big cities in Indonesia in recent years is a different feeling that the audience gets when watching live music events (Atiqah \& Ekasiwi, 2015).People who watch live music performances have more experience than only listening to music (Holt, 2010; De Rooij, 2013). There is also a sense of nostalgia felt by someone who is often triggered by music so that they are reminded of the experiences they felt at that time (Zentner et al., 2008), such as the Kahitna birthday concert, an Indonesian music group, succeeded in immersing the audience in a nostalgic atmosphere. Even though time has passed and Kahitna's age continues to grow, Yovie and his friends will always have a place in the hearts of Indonesian music listeners, especially their fans (Beritasatu, 2012). A person's nostalgic memory of their experiences creates a sense of attachments(Bahri-Ammari et al., 2016), as does a person's memory when they watch a musical performance of their favorite musician because nostalgia can also influence consumer behavior as a psychological nature ( Pascal et al., 2002; Marchegiani \& Phau, 2011; Muehling \& Pascal, 2011; Leong et al., 2015). In Indonesia, when a music show is well organized, it will have a positive impact on the audiences, one of them is the presence of a good relationship or a good brand attachment between the musician and his fans (Dewi \& Runyke, 2013; Tobing et al., 2017). A satisfying experience that is felt by someone also supports the emergence of a sense of trust, and a satisfying music performance will certainly impress and increase the brand trust from the fans to their favorite musician (Aydin et al., 2014; Carissa et al., 2020), and they will also provide various forms of support to their favorite musicians, as happened in Indonesia. Westlife influences their fans to purchase concert tickets in Jakarta, including young fans. Lipstick products from a brand to be sold out in all parts of Asia, including Indonesia, also happened after Suzy Bae, one of the famous singers in South Korea, promoted the product by uploading a photo of herself wearing the product. Music products such as CDs or DVDs and official merchandise products are also targeted by fans to make purchases, as happened to the Indonesian music group, JKT48 (Andraini, 2019). Someone who has memories of good experiences for them also has a tendency to relive those experiences (Toledo \& Lopes, 2016).

Many music lovers watch live music performances repeatedly to see firsthand their favorite musicians (Brown \& Knox, 2017), and music lovers in Indonesia are no exception (Irfani, 2019).However, previous studies applied in a music concert or live music performance industries can only be found in studies that discussed nostalgia, emotion, brand trust, and brand attachment (Black et al., 2007; De Rooij, 2013; Rhajbal et al., 2017). Several previous studies that examined repurchase intention variables were found to discuss more about social, ecommerce, customer satisfaction, sport equipment, and online purchasing in general (Butcher et al., 2002; Lin et al., 2011; Ibzan et al., 2016; Ali \& Bhasin, 2019; Khan et al., 2020), and no discussion that related to repurchase 
intention variables at music concerts or live music performances industry. Meanwhile, when someone already has a sense of brand trust and brand attachment to a product or a brand because of their nostalgic memory or nostalgia emotion (Wen et al., 2019) that person may have the repurchase intention to buy back products from that brand (Hellier et al., 2003; Tjiptono, 2004; Thomson et al., 2005; Lin et al., 2011; Tanojohardjo, 2014; Wu et al., 2015; Kaufmann et al., 2016; Wijaya \& Astuti, 2018), it indicates when someone has a satisfying experience while watching a music concert also has a tendency to relive that experience by having the intention to repurchase their favorite musician's concert ticket. Therefore, the repurchase intention variable will be added and the live music industry will be applied to this study. This research will analyze the effect of nostalgia emotion on brand trust and brand attachment towards repurchase intentions that are expected to provide more understanding of the connection between each variable in the chosen industry and captures a new insight to support further research related to the chosen variable and industry.

\section{Literature Review}

\subsection{Music Concert}

Music concert or musical performance is a step in the musical process during realization and transmitting the musical ideas to a listener (Carr et al., 2011). Cultural events, both significantly important for personal and collective experiences, are popular music concerts that offer social and cultural enrichments, branding, business ventures, along with destination marketing opportunities (Getz \& Page, 2016). For many artists, concert attendance is regarded to be a crucial factor within the music industry(Rushe, 2010; Waddell, 2009). Individuals are motivated to realize their desire, which motivated them in attending popular music concerts (Crompton \& McKay, 1997), hence making live music performances to be a popular music experience (Kulczynski et al., 2016).

\subsection{Nostalgia Emotion}

The sense of intimacy and comfort toward the desired past objects is referred to as nostalgia emotion(Holbrook \& Schindler, 1991; Wen et al., 2019). Nostalgia is an emotion that is mostly a positive experience related to longing. Emotions of nostalgia arise by reminiscing the life experiences of individuals and their loved ones (Sedikides et al., 2008). Nostalgia is mostly linked with past incidents and memories that occurred (Mercer, 2016).In the music industry, music can trigger emotions in their audience (Gabrielsson, 2011) and could be influenced by other factors, such as the location's atmosphere and presence of others (North et al., 2004; Scherer \& Coutinho, 2013), also most intensified sentimental experience could be experienced through live music performance (Lamont, 2011).

\subsection{Brand Attachment}

A strong cognitive and emotional connection linking the brand with itself is facilitated by brand attachment (Park et al., 2006).The customer-brand relation can be referred to as consumer's specific emotion on the brand, which includes pleasure, enjoyment, sorrow, affection, dissatisfaction, and so on (Wen et al., 2019). In the live music performance, an artist's performance is considered as something that is produced and created together that engages the audience, performers, and the music itself that results in a collaborative, mutually enjoyable activity, and these are the characteristics of an attachment (Kenny \& Holmes, 2018).

\subsection{Brand Trust}

Brand trust is referred to the perception of brands being dependable and liable on customers' interest and wellbeing, along with safe interactions with brands owned by consumers (Delgado-Ballester, 2011).The brand trust will be generated subsequently if the brand itself gives confidence in the value of their brand to consumers and direct consumer experience with brands can create and develop trust in brands (Doney \& Cannon, 1997). In the perspective of the music industry, Anshel \& Kipper (1988) stated that musical activity increased more trust than non-musical activities whether the participants were active or passive. The tendency to gain trust can be seen from the influence of two elements, music and activity, and any musical experience that contains these two elements could be expected to obtain similar results (Anshel \& Kipper, 1988).

\subsection{Repurchase Intention}

Individuals' intention on making another purchase of goods or services from the same business or person, who considers their current condition and future situations, is referred as repurchase intention (Hellier et al., 2003).Repurchase intention occurs after customers purchased a product or service before, and there is the satisfaction that causes customers to desire to make a repurchase (Nurhayati \& Murti, 2012). Consumers' intention on making a repurchase is defined by their future desire and depends on ratings from other consumers' previous transactional experiences (Hellier et al., 2003; Tjiptono, 2004).Sutisna (2001) also stated that when a customer gets a positive response to the past actions, his positive thoughts on what that person received will trigger the intention of individual to make the repurchases. In the music industry, the experience, engagement, novelty and 
practicality can also motivate repurchases of live concert tickets (Brown \& Knox, 2017). In performing arts, in which music is included, by understanding the driver of repurchase intention, the related parties can design a service offering, including putting music on a show or performance to retain and increase audience size (Hume et al., 2007).

\subsection{Hypothesis Development}

The development regarding trust continues to grow over time, and it is crucial to recognize it (Xingyuan et al., 2010). In its developments, nostalgia proneness is a strong determinant to validate predictivity of brands in having trust (Wen et al., 2019). Related to the current context, with brand nostalgia bringing back memories of past experiences that consumers experienced toward the brand, it is expected to raise brand's trust. It is mentioned that the brand trust is highly dependent on the degree of nostalgia, whereby high nostalgic intensity allows the creation of brand or interpersonal trust, and there is no exception to the music industry that when there is an intense emotional experience from the recent or past music activity it easier to increase trust between participants (Sun, 2015). A shift from rational cognitions reliance toward emotional reliance, which results in intimacy, develops the connection of interpersonal trust(Rosenbaum-Elliott et al., 2011).Previous studies have determined that brand nostalgia has a positive effect on brand trust to a substantial degree (Jensen et al., 2017). Therefore, the following hypothesis is tested:

\section{H1. Nostalgia Emotion has a significant positive impact on brand trust.}

In support of the relationship between nostalgia and attachment, multiple studies have determined that brand attachment happens after individuals refers back to their memories (Heilbrunn, 2001; Rhajbal et al., 2017). Therefore, the level of brand attachment is dependent of the intensity of nostalgic association (Rhajbal et al., 2017). Rhajbal (2017) has noted that brands can stimulate nostalgia through attachment by producing targeted goods or services with sentimental values. Sentimental memories and special experiences form the brand's foundation, extending beyond one generation and promoting continuity, connectedness, and support for bonding relationships. Similar to participants' emotions that are influenced by the enjoyable ambience and collaborative experiences of the past music activity that engages the audience, performers, and the music itself. Previous research discovered how nostalgia is one of the facets of brand attachment, and concluded how it positively affected brand attachment (Wildschut et al., 2006; Rhajbal et al., 2017).It has been observed that the higher levels of scent-evoked nostalgia result in a high level of scent-evoked positive effects, self-esteem, self-continuity, and life's social connectedness (Reid et al., 2015). Hence, the following hypothesis is tested:

\section{H2. Nostalgia Emotion has a significant positive impact on brand attachment.}

Pedeliento et al. (2016) state that individuals prefer to gain attachment toward brands, figures and celebrities in order to obtain security threats, physically and psychologically. Emotional attachment can be used to satisfy one's basic human needs (Thomson et al., 2005). In addition, the link established between brand and consumers that involves sentiments is referred as attachment. In this situation, it is stated that attachment is crucial in the development of consumer-brand relations, which acts as a driving factor for the intention to repurchase (Kaufmann et al., 2016; Lin et al., 2011). Wu et al. (2015) also mentioned that consumers who have attachments and developed feelings toward the brand will be more willing to repurchase the products of that brand. Hence, when customers already feel attached to some musicians and having a wonderful experience during their music concert, their intent in repurchasing tickets for the upcoming concert is highly probable. The result from the previous studies (Kaufmann et al., 2016; Lin et al., 2011) showed how the intent to repurchase is affected by brand attachment and having a positive influence. Hence, the hypothesis is developed as follows:

\section{H3. Brand Attachment has a significant positive impact on repurchase intention.}

Having trust in brand's product could decrease consumers' risks and uncertainties, and the increase in preference on certain brands is influenced when brands could stimulate their behavioral responses. Brand trust develops when consumers find the product chosen is from the best brand and meets their expectations (Tanojohardjo, 2014), which will increase their desire in future repurchase (Tjiptono, 2004). Hellier et al. (2003) mentioned that the intention to repurchase is also dependent on consumers' past transactional ratings, whereby trust and commitment on the brand affect repurchases (Wijaya \& Astuti, 2018), so if the customers feel satisfied after attending a music concert and have some trust to the singer or the band, they will have a tendency to repurchase the music concert tickets. Brand trust is also significantly determined to affect the intention to repurchase (Chiu et al., 2009; Fang et al., 2011; Fariz, 2018). Hence, the hypothesis is developed as follows: 
H4. Brand Trust has a significant positive impact on repurchase intention.

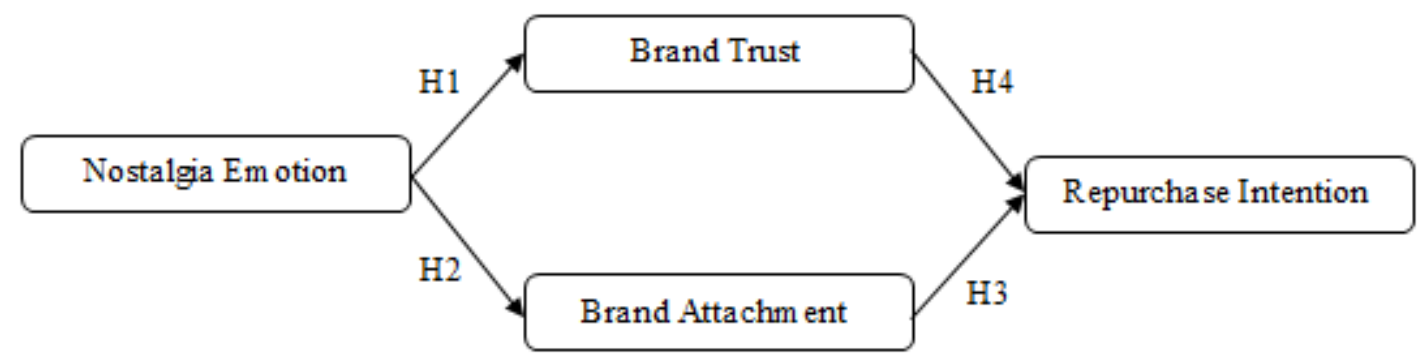

Figure 1. Theoretical Model

\section{Research Method}

\subsection{Measurement}

In measuring nostalgia emotions, five items by Ju et al. (2016) were used, and three items by Aydin et al. (2014) and Horppu et al. (2008) were utilized in measuring brand trust. Three items of Leonardo et al. (2018) were used in measuring brand attachment, and purchase intention used three items measurement by Ku \& Lin (2018). A five-point Likert scale was also used with a range of 1 "strongly disagree" to 5 "strongly agree". The questionnaire is made up by three sections. Respondents were asked one screening question in the first section. Second, there was one question about whose music concerts have the respondents ever watched and nine questions related to respondents' demography; gender, age, occupation, income, educational background, marital status, frequency of watching music concerts in the last five years, favorite music genre, and experience watching music concerts. The third section contained the main questions that contained measure scales based on prior research of nostalgia emotion, brand trust, brand attachment, and repurchase intention.

\subsection{Data collection and analysis}

The data used for the current study were collected from people who have watched music concerts or live music performances in Jakarta. The main data collection tool in this study is an online survey. Respondents were asked to answer inquiries regarding the music concert that they had recently attended. In the selection of respondents, convenience sampling technique was applied, which resulted in 120 respondents. Smart PLS is used to analyze the research variable in structural equation modeling (PLS-SEM).

\section{Data Analysis}

\subsection{Profile of Respondents}

As shown in Table 1, the profile respondents consist of the majority being 21-30 years old (79.2\%), male $(56.9 \%)$, employees $(65.3 \%)$, ever had the experience of watching music concerts abroad $(91.7 \%)$, and had a bachelor degree as an educational level (79.2\%). It also shows that $72.2 \%$ of respondents are single, and $62.5 \%$ choose pop as their favorite music genre.

Table 1. Profile of Respondents

\begin{tabular}{|l|l|l|}
\hline Age & Total & $\%$ \\
\hline$\leq 20$ years old & 5 & $4.2 \%$ \\
\hline $21-30$ years old & 95 & $79.2 \%$ \\
\hline $31-40$ years old & 20 & $16.6 \%$ \\
\hline Gender & & \\
\hline Male & 68 & $56.9 \%$ \\
\hline Female & 52 & $43.1 \%$ \\
\hline Occupation & & \\
\hline
\end{tabular}




\begin{tabular}{|c|c|c|}
\hline Employee & 78 & $65.3 \%$ \\
\hline Student & 17 & $13.9 \%$ \\
\hline Entrepreneur & 2 & $1.4 \%$ \\
\hline Other & 23 & $19.4 \%$ \\
\hline \multicolumn{3}{|l|}{ Monthly Income } \\
\hline$<\operatorname{Rp} 5.000 .000$ & 57 & $47.2 \%$ \\
\hline Rp 5.000.000 - Rp 10.000.000 & 40 & $33.3 \%$ \\
\hline Rp 10.000.001 - Rp 15.000.000 & 13 & $11.1 \%$ \\
\hline > Rp 15.000.000 & 10 & $8.3 \%$ \\
\hline \multicolumn{3}{|l|}{ Educational Level } \\
\hline High School Graduate & 17 & $13.9 \%$ \\
\hline Diploma Degree & 2 & $1.4 \%$ \\
\hline Bachelor Degree & 95 & $79.2 \%$ \\
\hline Master Degree & 6 & $5.6 \%$ \\
\hline \multicolumn{3}{|l|}{ Marital Status } \\
\hline Single & 87 & $72.2 \%$ \\
\hline Married & 33 & $27.8 \%$ \\
\hline \multicolumn{3}{|c|}{ Frequency of watching music concerts in the last 5 years } \\
\hline $1-3$ & 100 & $83.3 \%$ \\
\hline $4-6$ & 10 & $8.4 \%$ \\
\hline$>6$ & 10 & $8.3 \%$ \\
\hline \multicolumn{3}{|l|}{ Favorite Music Genre } \\
\hline Classic & 15 & $12.5 \%$ \\
\hline Jazz & 10 & $8.3 \%$ \\
\hline Blues & 3 & $2.8 \%$ \\
\hline Pop & 75 & $62.5 \%$ \\
\hline Country & 2 & $1.4 \%$ \\
\hline Reggae & 3 & $2.8 \%$ \\
\hline Other & 12 & $9.7 \%$ \\
\hline \multicolumn{3}{|c|}{ Experience of watching music concerts abroad } \\
\hline Yes & 110 & $91.7 \%$ \\
\hline No & 10 & $8.3 \%$ \\
\hline
\end{tabular}




\subsection{Results}

In this study, the reliability of internal coherence, convergent validity, and discriminant validity was evaluated. To evaluate the validity of convergent, the value of outer loading or loading factor was utilized, and Average Variance Extracted (AVE) was evaluated. As a rule of thumb, if the factor loading value is $>0.7$ and the average variance extracted (AVE) by a construct's products is at least 0.50 , then the convergent validity is in the good category (Chin \& Gopal, 1995). The composite reliability and Cronbach's alpha coefficient are used to determine the internal consistency reliability. Composite reliability results $>0.7$ are shown to be highly reliable, as well as alpha score greater than>0.6 (Thorndike, 1995). The Fornell-Lacker criteria approach was used to measure the validity of the discriminant by comparing the link of all paired constructs with each construct's AVE square roots, whereby the AVE square root should be greater than the latent construct's correlation (Ab Hamid et al., 2017).

In Table 2, it shows the convergent validity and the internal consistency reliability results with the load factor of all elements being greater than 0.7 and the AVE value of each variable is greater than 0.5 . This determines that the convergent validity is in the good category and is accurate since all variables have a cumulative reliability value greater than 0.7 and all variables have alpha scores greater than 0.6.

Table 2. Reliability and Validity

\begin{tabular}{|c|c|c|c|c|c|}
\hline Variable & Item & Factor Loading & Cronbach's Alpha & $\mathrm{CR}$ & AVE \\
\hline \multirow{3}{*}{$\begin{array}{l}\text { Brand Attachment } \\
\text { (BA) }\end{array}$} & BA1 & 0.715 & \multirow[t]{3}{*}{0.721} & \multirow[t]{3}{*}{0.842} & \multirow[t]{3}{*}{0.641} \\
\hline & BA2 & 0.849 & & & \\
\hline & BA3 & 0.831 & & & \\
\hline \multirow{3}{*}{$\begin{array}{l}\text { Brand Trust } \\
\text { (BT) }\end{array}$} & BT1 & 0.753 & \multirow[t]{3}{*}{0.656} & \multirow[t]{3}{*}{0.813} & \multirow[t]{3}{*}{0.592} \\
\hline & BT2 & 0.796 & & & \\
\hline & BT3 & 0.759 & & & \\
\hline \multirow{5}{*}{$\begin{array}{l}\text { Nostalgia Emotion } \\
\text { (NE) }\end{array}$} & NE1 & 0.737 & \multirow[t]{5}{*}{0.841} & \multirow[t]{5}{*}{0.878} & \multirow[t]{5}{*}{0.591} \\
\hline & NE2 & 0.761 & & & \\
\hline & NE3 & 0.766 & & & \\
\hline & NE4 & 0.768 & & & \\
\hline & NE5 & 0.811 & & & \\
\hline \multirow{3}{*}{$\begin{array}{l}\text { Repurchase Intention } \\
\text { (RI) }\end{array}$} & RI1 & 0.883 & \multirow[t]{3}{*}{0.84} & \multirow[t]{3}{*}{0.902} & \multirow[t]{3}{*}{0.755} \\
\hline & RI2 & 0.88 & & & \\
\hline & $\mathrm{RI} 3$ & 0.843 & & & \\
\hline
\end{tabular}


The results of discriminant validity, shown in Table 3, signify how the square root of AVE is greater than relation of any paired construct shown through the diagonal bold square root of AVE.

Table 3. Discriminant Validity

\begin{tabular}{|l|l|l|l|l|}
\hline Var & BA & BT & NE & RI \\
\hline BA & $\mathbf{0 . 8 0 1}$ & & & \\
\hline BT & 0.711 & $\mathbf{0 . 7 7}$ & & \\
\hline NE & 0.517 & 0.491 & $\mathbf{0 . 7 6 9}$ & \\
\hline RI & 0.709 & 0.617 & 0.463 & $\mathbf{0 . 8 6 9}$ \\
\hline
\end{tabular}

Note: The diagonal values are the square root of AVE that shows the correlation between variables.

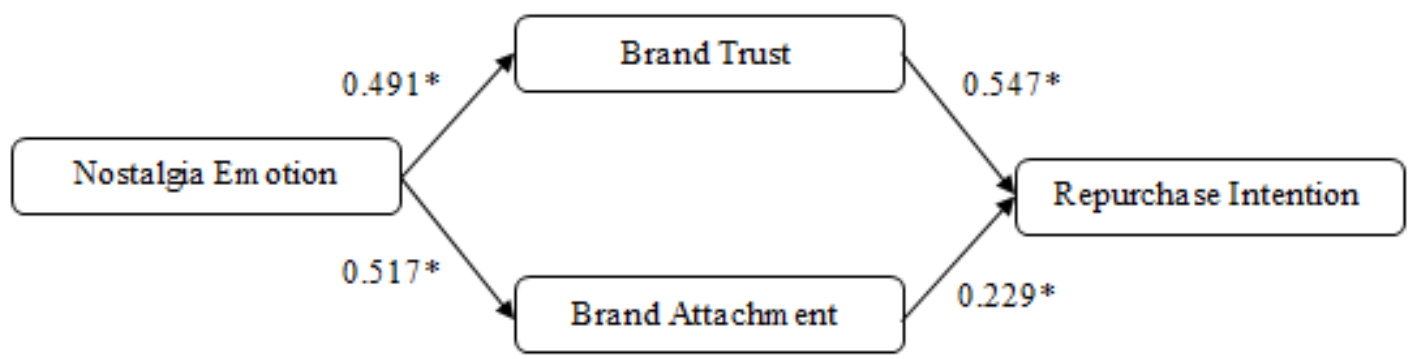

Note: $*$ p-value $<0.05$

Figure 2. Hypothesis Test Results

Hypothesis testing used in this study uses the PLS-SEM method that carries out the bootstrapping process with the SmartPLS 3.0 computer program (Alfa et al., 2017) by seeing significant value between $\mathrm{T}$ statistics and $\mathrm{P}$ values. Path coefficient, T-statistics, and P-values were used for descriptive statistics. The path coefficient represents the original sample value of the variables studied, while the T-statistic is the ratio of the parameter's estimated value to its standard error from the hypothesized value. The T-statistic in the T-test is to decide whether the null hypothesis be supported or rejected. T-test for independent samples is by comparing the average of two groups of variables in order in determining the hypothesis validity test results. The T-statistic is the average of the parameter's expected value to its standard error from the hypothesized value. P-value is the amount of opportunity or probability observed from the statistics test and the hypothesis accepted if the P-values < 0.05 (Lakens, 2019).

Table 4. Hypothesis Test Results

\begin{tabular}{|l|l|l|c|c|c|}
\hline Hypothesis & Path & Path Coefficient & $\begin{array}{c}\text { T- } \\
\text { stat }\end{array}$ & P-value & Conclusion \\
\hline H1 & NE $\rightarrow$ BT & 0.547 & 6.209 & 0.000 & Supported \\
\hline H2 & NE $\rightarrow$ BA & 0.229 & 7.335 & 0.000 & Supported \\
\hline H3 & BA $\rightarrow$ RI & 0.517 & 5.268 & 0.000 & Supported \\
\hline H4 & BT $\rightarrow$ RI & 0.491 & 2.075 & 0.038 & Supported \\
\hline
\end{tabular}

The hypothesis result in Table 4 describes the structural model that has been made. Based on the result of four hypotheses, the P-value of variable path for $\mathrm{H} 1, \mathrm{H} 2$, and $\mathrm{H} 3$ is 0.000 and 0.038 for $\mathrm{H} 4$. It concluded that all 
hypotheses can be supported because each of the variable paths has shown that the $\mathrm{P}$-value is $<0.05$. All of them can be accepted, which shows how significantly effective the independent variable of the dependent variable is

\section{Discussions}

This study has found that nostalgia emotion can affect brand trust and the brand attachment for music lovers or music concert attendees in Jakarta that build their intention toward repurchasing the upcoming live music performance or music concert tickets in the future. As experienced by one of the Korean music fans who watched Korean music concerts in Jakarta and repeatedly watched her favorite idol's live performances after her first time because she wants to see and feel again that experience (wolipop.detik.com, 2019). Nostalgia emotion makes customers remember their previous experiences that will enhance their trust with the brand. A good and memorable live music performance experienced by someone can generate a sense of trust in the musician. It was confirmed that nostalgia has good predictive validity and a positive impact on brand trust to a degree (Jensen et al., 2017; Wen et al., 2019). Not only that, it was also discovered how customer relies on their previous memories and experiences prior to having attachment and nostalgia on the brand. When there is a sense of nostalgia that comes from attending past live music performances, it can also build the attendees' attachment to the musician. The study by Rhajbal et al. (2017) is in support of the obtained result which states how the greater the nostalgic connection from the customer, the greater the attachment to the brand. This research discovered the correlation among brand attachment and the intention to repurchase. The interaction between the musician and the attendees can drive the brand attachment of the musician. Actions that only musicians and their fans can do at a music concert or live music performance such as seeing their idols in person or greeting each other and even singing along can increase that sense of attachment, and that kind of experience can build the intention to repurchase the musician's concert ticket so they can witness the next performance. It is supported by Kaufmann et al. (2016), Lin et al. (2011), and Wu et al. (2015) which state that the attachment between the customer and the brand can drive the intention to repurchase products because there is a connection between them, which explains how the already existing attachment between consumers and brands will result to the willingness of repurchase. The result also found that the satisfying experience gained from the previous live music performance delivered by the musician which is an experience that is more than just listening to a song can make the attendees feel a sense of trust. This sense of trust can trigger that person to be more likely to have an intention to repurchase that musician's concert ticket for the next performance. It affirms previous studies' findings (Chiu et al., 2009; Fang et al., 2011; Fariz, 2018) that the intent on making repurchase is significantly affected by brand trust. It explains that brand trust exists when consumers feel that the product from the brand, they choose can fulfill their expectations and are more likely to repurchase something once they trust a brand.

\section{Conclusions}

This study concluded that nostalgia emotion owned by a person can affect the person's brand trust and brand attachment towards the repurchase intention especially in this case in the music industry. The more a person has a nostalgic emotion to a particular brand, that person is likely to have trust and get attached to that brand and when a person already has trust and gets attached, then the possibility of that person having the intention to repurchase products from that brand will be higher too. Attendees with a good memory when watching live music performances will feel attached and trust the musician from the moments of their experiences in the past and want to feel and experience that similar moment again. That desire to relive the experience from the past aroused their intention to repurchase tickets for live music performances of the same musician. This is why individuals willingly attend their musician's concert numerous times (Schippers, 2015).

\section{Managerial Implications}

This study provides essential implications for business sectors, especially for event organizers and musicians to hold a concert or music event by presenting something that fans can enjoy only when they attend live music concerts. For example, the song arrangement that is specifically played when the musician holds a concert is different from the recorded song to make the concert more special. A stage action that involves the interaction between musicians and fans during the event also can be done. Delivering a song and performing it in different ways and arrangements will make the experience of the attendees even more special. The interaction between musicians and fans needs to be done to build a bond between the two (Shoda et al., 2016; Brown \& Knox, 2017; Hödl et al., 2020). Things that attendees cannot get other than when attending a live music performance such as good interactions between musicians and fans make music concerts as a medium for fans to meet their idols. The stage action and good interaction during the event will give the attendees a memorable experience. The bond between musicians and fans and the trust that comes from feeling nostalgic about the experience of watching previous concerts, event organizers can take advantage of this to attract fans to buy back the musician's concert tickets for upcoming events by offering an exclusive experience that can only be felt when someone comes to a 
paid concert. In addition, providing a platform for fans such as offering photo sessions and greeting fans directly who buy special tickets can be done to attract interest, or even give souvenirs as a form of gratitude from musicians to their fans who watched the concert and also a special place provided by the organizer for fans in order to be able to convey fan letters and gifts to his idols, which are expected to provide satisfaction for the attendees of the music concert event and increase the desire to buy back concert tickets at the future.

\section{Suggestion For Future Studies}

There are some drawbacks to this analysis that can be developed in future studies. By only providing an overview of music concerts in Jakarta in terms of using the nostalgic appeal of emotions to the audience, this study needs a more extensive sample collected from more cities in Indonesia to provide more comprehensive data. This research can also be extended to other objects than music concerts or live music events for future studies. Other measurements of nostalgic triggers through various elements of nostalgia could be further examined, along with the effectiveness of different variables such as brand image or even advertising engagement sector. Reexamined to explore the difference between the appeal of emotional nostalgia and the other attraction that is commonly used as we examine the music concert in Jakarta also can be done. In addition, differences in music concerts in different regions and media can also be examined in the future.

\section{References}

Ab Hamid, M. R., Sami, W., \& Mohmad Sidek, M. H. (2017). Discriminant Validity Assessment: Use of Fornell \& Larcker criterion versus HTMT Criterion. Journal of Physics: Conference Series, 890(1). https://doi.org/10.1088/1742-6596/890/1/012163

Alfa, A. A. G., Rachmatin, D., \& Agustina. (2017). ANALISIS PENGARUH FAKTOR KEPUTUSAN KONSUMEN DENGAN STRUCTURAL EQUATION MODELING PARTIAL LEAST SQUARE. FPMIPA UPI.

Ali, A., \& Bhasin, J. (2019). Understanding Customer Repurchase Intention in E-commerce: Role of Perceived Price, Delivery Quality, and Perceived Value. Jindal Journal of Business Research.

Andraini, W. H. (2019). PENGARUH TINGKATAN CELEBRITY WORSHIP TERHADAP PERILAKU KONSUMTIF REMAJA DALAM PEMBELIAN PRODUK YANG BERKAITAN DENGAN IDOLA. Universitas Negeri Jakarta.

Anshel, A., \& Kipper, D. A. (1988). The influence of group singing on trust and cooperation. Journal of Music Therapy, 25(3). https://doi.org/10.1093/jmt/25.3.145

Atiqah, N., \& Ekasiwi, N. N. (2015). Fleksibilitas pada Stadium Musik Konser Pop -Rock. 4(2), 56-59.

Aydin, G., Ar, A. A., \& Taskin, Ç. (2014). The Role of Brand Trust on Parents Purchase Intentions of Baby-Care Products. Doğuş Üniversitesi Dergisi, 2(15), 165-180. https://doi.org/10.31671/dogus.2018.84

Bahri-Ammari, N., Van Niekerk, M., Ben Khelil, H., \& Chtioui, J. (2016). The effects of brand attachment on behavioral loyalty in the luxury restaurant sector. International Journal of Contemporary Hospitality Management, 28(3), 559-585. https://doi.org/10.1108/IJCHM-10-2014-0508

Beritasatu. (2012). Hanyut Dalam Nuansa Nostalgia di Konser Ulang Tahun Kahitna ke 26. Beritasatu. https://www.beritasatu.com/amp/hiburan/59092/hanyut-dalam-nuansa-nostalgia-di-konser-ulang-tahunkahitna-ke-26

Black, G. C., Fox, M. A., \& Kochanowski, P. (2007). . Concert tour success in North America: An examination of the top 100 tours from 1997 to 2005. Popular Music and Society, 30(2), 149-172.

Brown, S. C., \& Knox, D. (2017). Why go to pop concerts? The motivations behind live music attendance. Musicae Scientiae, 21(3). https://doi.org/10.1177/1029864916650719

Butcher, K., Sparks, B., \& O'Callaghan, F. (2002). Effect of social influence on repurchase intentions. Journal of Services Marketing, 16(6). https://doi.org/10.1108/08876040210443382

Carissa, A., Natalia, J., Lasini, M., \& Gunadi, W. (2020). Understanding The Role Of Sensory, Emotional, Social And Memorable Experiences In Behavioural Intention Of Indonesia's Music Concert Industry. International Journal of Scientific \& Technology Research, 9(1).

Carr, A. B., Thomas, Patrick, J., Foss, \& Lukas. (2011). Musical Performance. Encyclopedia Britannica. http://www.guardian.co.uk/business/2010/dec/30/rock-concert-sales-plunge

Chin, W. W., \& Gopal, A. (1995). Adoption intention in gss: Relative importance of beliefs. ACM SIGMIS Database, 26(2-3). https://doi.org/10.1145/217278.217285

Chiu, C., Chang, C., Cheng, H., \& Fang, Y. (2009). Determinants of customer repurchase intention in online shopping. Online Information Review, 33(4), 761-784.

Crompton, J. L., \& McKay, S. L. (1997). Motives of visitors attending festival events. Annals of Tourism Research, 24(2). https://doi.org/10.1016/s0160-7383(97)80010-2

De Rooij, P. (2013). Customer loyalty to performing arts venues: Between routines and coincidence. Tilburg University. 
Delgado-Ballester, E. (2011). Development and validation of a brand trust scale. https://markenmanagement.files.wordpress.com/2012/01/\%0AElena-delgado-ballester_developmentandvalidation-of-a-brand-trust-scale.pdf

Dewi, M., \& Runyke, M. (2013). Peran Public Relations dalam Manajemen Event. Jurnal Komunikasi, 8(1), 7990.

Doney, P. M., \& Cannon, J. P. (1997). An examination of the nature of trust in buyer-seller relationships. Journal of Marketing, 61(2). https://doi.org/10.2307/1251829

Fang, Y.-H., Chiu, C.-M., \& Wang, E. T. G. (2011). Understanding Customers' Satisfaction and Repurchase Intentions: An Integration of IS Success Model, Trust, and Justice. Internet Research, 21(4).

Fariz, A. (2018). Peningkatan Brand Preference Dan Brand Trust Melalui Brand Identity Terhadap Repurchase Intention. UNISSULA.

Gabrielsson, A. (2011). Emotions in strong experiences with music. In Music and Emotion: Theory and research.

Getz, D., \& Page, S. J. (2016). Event studies: theory, research and policy for planned events. In Routledge.

Heilbrunn, B. (2001). Les facteursd'attachement du consommateur à la marque. In Thèse pour l'obtention du titre de docteuren Sciences de Gestion. Université Paris-Dauphine.

Hellier, P. K., Geursen, G. M., Carr, R. A., \& Rickard, J. A. (2003). Customer Repurchase Intention, A General Structural Equation Model. European Jurnal Marketing, 37(11/12), 1762-1800.

Hödl, O., Bartmann, C., Kayali, F., Löw, C., \& Purgathofer, P. (2020). Large-scale audience participation in live music using smartphones. Journal of New Music Research, 49(2). https://doi.org/10.1080/09298215.2020.1722181

Holbrook, M. B., \& Schindler, R. M. (1991). Echoes of the Dear Departed Past: Some Work in Progress On Nostalgia. In Advances in Consumer Research (Vol. 18).

Holt, F. (2010). The economy of live music in the digital age. European Journal of Cultural Studies, 13(2), 243261. https://doi.org/10.1177/1367549409352277

Hume, M., Mort, G. S., \& Winzar, H. (2007). Exploring repurchase intention in a performing arts context: who comes?and why do they come back? International Journal of Nonprofit and Voluntary Sector Marketing, 12, $135-148$.

Ibzan, E., Balarabe, F., \& Jakada, B. (2016). Consumer Satisfaction and Repurchase Intentions. Developing Country Stusies, 6(2), 96-100.

Irfani, F. (2019). Prediksi Musik Indonesia 2019: Nostalgia hingga Kejayaan Hip-Hop. Tirto.Id. https://tirto.id/prediksi-musik-indonesia-2019-nostalgia-hingga-kejayaan-hip-hop-dcNW

Jensen, S., Ohlwein, M., \& Fischer, D. (2017, June 21-23). The glory of the past - do nostalgic brands appeal to Generation Y? 5th International Conference on Contemporary Marketing Issue ICCMI, 42-49, Thessaloniki, Greece. https://scholar.google.com/citations?user=nEbXcDYAAAAJ\&hl=en

Kaufmann, H. R., Petrovici, D. A., Filho, C. G., \& Ayres, A. (2016). Identifying moderators of brand attachment for driving customer purchase intention of original vs counterfeits of luxury brands. Journal of Business Research, 69(12). https://doi.org/10.1016/j.jbusres.2016.05.003

Kenny, D. T., \& Holmes, J. (2018). Attachment quality is associated with music performance anxiety in professional musicians: An exploratory narrative study. Polish Psychological Bulletin, 49(3). https://doi.org/10.24425/119496

Khan, M. A., Panditharathna, R., \& Bamber, D. (2020). 28 Online store brand experience impacting on online brand trust and online repurchase intention: The moderating role of online brand attachment. European Journal of Management and Marketing Studies, 5(1).

$\mathrm{Ku}, \mathrm{T}$. H., \& Lin, T. L. (2018). Effects of luxury brand perceptions on brand attachment and purchase intention: A comparative analysis among consumers in China, Hong Kong and Taiwan. South African Journal of Business Management, 49(1). https://doi.org/10.4102/sajbm.v49i1.6

Kulczynski, A., Baxter, S., \& Young, T. (2016). Measuring motivations for popular music concert attendance. Event Management, 20(2), 239-254. https://doi.org/10.3727/152599516X14643674421816

Lakens, D. (2019). The practical alternative to the p-value is the correctly used p-value. PsyArXiv.

Lamont, A. (2011). University students' strong experiences of music: Pleasure, engagement, and meaning. Musicae Scientiae, 15(2), 229-249. https://doi.org/10.1177/1029864911403368

Leong, A. M. W., Yeh, S., Hsiao, Y.-C., \& Huan, T.-C. (2015). Nostalgia as travel motivation and its impact on tourists' loyalty. Journal of Business Research, 68(1). https://doi.org/10.1016/j.jbusres.2014.05.003

Lin, Y.-T., Chen, S.-C., \& Hung, C.-S. (2011). The impacts of brand equity, brand attachment, product involvement and repurchase intention on bicycle users. African Journal of Business Management, 5(14). https://doi.org/10.5897/AJBM10.862

Marchegiani, C., \& Phau, I. (2011). The value of historical nostalgia for marketing management. Marketing Intelligence \& Planning, 29(2), 108-122. https://doi.org/10.1108/02634501111117575

Mercer, M. (2016). Is nostalgia a mixed emotion? Evidence from emotional experience and facial expressions of emotion. http://trace.tennessee.edu/cgi/viewcontent.cgi?article=2931\&context=utk_chanhonoproj 
Muehling, D. D., \& Pascal, V. (2011). An Empirical Investigation of the Differential Effects of Personal, Historical, and Non-Nostalgic Advertising on Consumer Responses. Journal of Advertising, 40(2), 107-122. https://doi.org/10.2307/23048708

North, A. C., Hargreaves, D. J., \& Hargreaves, J. J. (2004). Uses of Music in Everyday Life. Music Perception, 22(1), 41-77. https://doi.org/10.1525/mp.2004.22.1.41

Nurhayati, \& Murti, W. W. (2012). Analisis Faktor-faktor yang Mempengaruhi Minat Beli Ulang Masyarakat Terhadap Produk Handphone. Value Added, 8(2), 53.

Park, C. W., MacInnis, D. J., \& Priester, J. (2006). Brand attachment: Constructs, consequences, and causes. In Foundations and Trends in Marketing (Vol. 1, Issue 3). https://doi.org/10.1561/1700000006

Pascal, V. J., Sprott, \& Muehling, D. D. (2002). The influence of evoked nostalgia on consumers' response to advertising: an exploratory study. Journal of Current Issues and Research in Advertising, 24(1), 39-49.

Pedeliento, G., Andreini, D., Bergamaschi, M., \& Salo, J. (2016). Brand and product attachment in an industrial context: the effects on brand loyalty. International Marketing Management, 53, 194-206.

Reid, C. A., Green, J. D., Wildschut, T., \& Sedikides, C. (2015). Scent-evoked nostalgia. Memory, 23(2). https://doi.org/10.1080/09658211.2013.876048

Rhajbal, Z., Khouilid, M., Saligane, L., \& Chakor, A. (2017). Brand Attachment and Brand Loyalty: The Moderating Role of Nostalgic Connections. IOSR Journal of Humanities and Social Science, 22(6), $24-34$.

Rosenbaum-Elliott, R., Percy, L., \& Pervan, S. (2011). Strategic Brand Management (Second). Oxford University Press.

Rushe, D. (2010). Rock concert sales plunge as recession forces promoters into discounts. The Guardian. http://www.guardian.co.uk/business/2010/dec/30/rock-concert-sales-plunge

Scherer, K., \& Coutinho, E. (2013). How music creates emotion: a multifactorial process approach. The Emotional Power of Music: Multidisciplinary Perspectives on Musical Arousal, Expression, and Social Control.

Schippers, M. Y. (2015). Live Music Concert Attendees. 1-44. https://palmstiernass.ga/pub/32748/SchippersMarjolein.pdf

Sedikides, C., Wildschut, T., Arndt, J., \& Routledge, C. (2008). Nostalgia: Past, present, and future. In Current Directions in Psychological Science (Vol. 17, Issue 5). https://doi.org/10.1111/j.1467-8721.2008.00595.x

Shoda, H., Adachi, M., \& Umeda, T. (2016). How live performance moves the human heart. PLoS ONE, 11(4). https://doi.org/10.1371/journal.pone.0154322

Sun, M. G. (2015). Review on nostalgia consumer, purchase intention and brand attachment. Review of Economy and Management, 5, 48-57.

Tanojohardjo, G. A. (2014). Analisa Hedonic Value dan Utilitarian Value terhadap Brand Trust dengan Brand Satisfaction sebagai Variabel Intervening pada Produk Pewarnaan LOréal Professionnel. Jurnal Strategi Pemasaran, 2(1), 1-11.

Thomson, M., MacInnis, D. J., \& Park, C. W. (2005). The ties that bind: measuring the strength of consumers' emotional attachments to brands. Journal of Consumer Psychology, 15, 77-91.

Thorndike, R. M. (1995). Book Review : Psychometric Theory (3rd ed.) by Jum Nunnally and Ira Bernstein New York: McGraw-Hill, 1994, xxiv + 752 pp. Applied Psychological Measurement, 19(3). https://doi.org/10.1177/014662169501900308

Tjiptono, F. (2004). Pemasaran Jasa. Bayumedia Publishing.

Tobing, C. M. C. L., Perbawasari, S., \& Erdinaya, L. K. (2017). MANAJEMEN SPECIAL EVENT AJB BUMIPUTERA 1912 BANDUNG MELALUI CUSTOMER GATHERING. Jurnal Ilmiah Ilmu Hubungan Masyarakat, 2(1), 13-22.

Toledo, A. C., \& Lopes, E. L. (2016). Effect of Nostalgia on Customer Loyalty to Brand Post-Merger / Acquisition. Brazilian Administration Review, 13(1), 33-55.

Triwijanarko, R. (2017). Menilik Ramainya Fenomena Festival Musik di Indonesia. Marketeers. https://marketeers.com/ramainya-festival-musik-di-indonesia/

Waddell, R. (2009). Year-end: Global concert business remains strong in 2009. Billboard.Com. http://www.billboard.com/biz/articles/news/touring/1261918/year-end-global-concert-business-remainsstrong-in-2009

Wen, T., Qin, T., \& Liu, R. R. (2019). The impact of nostalgic emotion on brand trust and brand attachment: An empirical study from China. Asia Pacific Journal of Marketing and Logistics, 31(4). https://doi.org/10.1108/APJML-09-2018-0390

Wijaya, H. R., \& Astuti, S. R. T. (2018). The Effect of Trust and Brand Image to Repurchase Intention in Online Shopping. International Conference on Economics, Business and Economic Education 2018, 915-928.

Wildschut, T., Sedikides, C., Arndt, J., \& Routledge, C. (2006). Nostalgia: Content, triggers, functions. Journal of Personality and Social Psychology, 91(5). https://doi.org/10.1037/0022-3514.91.5.975

Wu, W. Y., Anridho, N., \& Liao, Y. K. (2015). The role of associative and relational moderators on experiential branding. Proceedings of Make Learn and TIIM Joint International Conference 2015, 593-602. 
Xingyuan, W., Li, F., \& Wei, Y. (2010). How Do They Really Help? An Empirical Study of the Role of Different Information Sources in Building Brand Trust. Journal of Global Marketing, 23(3), 243-252.

Zentner, M., Grandjean, D., \& Scherer, K. R. (2008). Emotions evoked by the sound of music: characterization, classification, and measurement. Emotion, 8(4), 494-521. https://doi.org/10.1037/1528-3542.8.4.494 